\title{
МИСТЕЦЬКІ ПОШУКИ РЕЖИСЕРІВ СЄВЄРОДОНЕЦЬКА XX СТолІття
}

\author{
Світлана Уланова ${ }^{1 a}$, Кирило Майкут²a, Анастасія Адначева-Пономаренко ${ }^{3 b}$ \\ ${ }^{1}$ доктор філософських наук, професор; e-mail: golubtsova@i.ua; ORCID: 0000-0001-5463-5659 \\ ${ }^{2}$ мaгiстр; e-mail: kirillmaik@ukr.net; ORCID: 0000-0003-1012-697X \\ ${ }^{3}$ магістр; e-mail: nastaponomarenko366@gmail.com; ORCID: 0000-0003-0693-0973 \\ а Луганська державна академія культури і мистецтв, Київ, Україна \\ ь Луганський обласний академічний український музично-драматичний театр, Сєвєродонецьк, Україна
}

\begin{abstract}
Анотація
Мета дослідження - схарактеризувати творчо-організаційну діяльність провідних режисерів Сєвєродонецька у XX ст. Методологія дослідження. У процесі дослідження використано такі методи: історичний - для осмислення постатей О. Бірюстюкова, О. Шмаля та О. Олександрова в театральному мистецтві Сєвєродонецька; історико-біографічний - для аналізу контексту епохи та естетико-художніх векторів часу, що впливали на формування художніх підходів означених митців; компаративно-типологічний - для диференційованого порівняння творчого доробку режисерів. Наукова новизна. Уперше систематизовано та аналітично осмислено творчо-організаційну діяльність О. Бірюстюкова, О. Шмаля та О. Олександрова в контексті еволюції театрального мистецтва Сєвєродонецька у XX cт. Висновки. Сєвєродонецький народний театр під орудою О. Бірюстюкова виконував не тільки соціокультурні, але й освітньо-виховні функції для містян. Творчо-організаційна діяльність О. Шмаля стала сучасною імплементацією принципу «об'єктивного мистецтва» Г. Гурджиєва, зокрема через упровадження авторської методики роботи з акторами. Режисура О. Олександрова збагатила палітру театрального життя Сєвєродонецька своєю епатажністю та авангардизмом. Загалом відносно коротка історія розвитку театрального мистецтва Сєвєродонецька свідчить про те, що динаміку цього процесу визначила тенденція, яка характерна і для загальнонаціональних процесів становлення українського театрального життя: від самодіяльних його форм до професійних. Аналіз останніх свідчить про їхній активний розвиток завдяки використанню нових режисерських підходів, що сприяли зростанню акторської майстерності колективів і збагаченню репертуарної палітри щодо відродження національних культурних традицій. Режисерські пошуки та організаційно-творча діяльність О. Бірюстюкова, О. Шмаля та О. Олександрова стали вагомим внеском у розвиток театрального мистецтва Сєвєродонецька у XX ст. - воно стрімко та різновекторно розвивалося від локального аматорського театрального колективу однодумців до провідного регіонального професійного театрально-видовищного закладу культури.
\end{abstract}

Ключові слова: театральне мистецтво; XX століття; Сєвєродонецьк; режисер О. Бірюстюков; О. Шмаль; О. Олександров 


\section{Постановка проблеми}

Сучасне українське театральне мистецтво піддається суттєвим трансформаціям, які обумовлені новими соціальними функціями культури як складової суспільного життя. Їхня спрямованість на розкриття психологічного стану сучасного українця вимагає оновлення традиційних форм театральної діяльності й адаптації до завдань відродження національної спадщини, що надає театрові як окремому виду мистецтва суттєву перевагу над іншими формами культурної діяльності.

\section{Аналіз останніх досліджень і публікацій}

Значний внесок у становлення та розвиток українського театрального мистецтва зробили аматорські гуртки, що почали з'являтися в середині XIX ст. Характеризуючи діяльність народного колективу в Сєвєродонецьку, необхідно було більш детально визначити специфіку українського аматорського театрального мистецтва. 3 відомих джерел можна виокремити працю Л. Дорогих (1998), в якій автор стверджує, що на етапі свого становлення аматорське мистецтво набуло великого піднесення та активізації, що обумовлено тогочасною популяризацією національно-культурного руху.

Цей процес підтверджують і архівні документи, що відображають функціонування театрального мистецтва в Сєвєродонецьку на період його становлення. В історичному екскурсі знаходимо прізвище О. Бірюстюкова, який першим у місті створив театральний у загальноприйнятому значенні цього слова колектив. Згодом саме цей колектив трансформувався в перший у Сєвєродонецьку народний театр (Васильев, 1999).

Сьогодні театральне мистецтво спонукає до вивчення його не тільки в загальнонаціональних характеристиках, але й у регіональних формах функціонування. Особливо актуальною ця проблема $є$ для українського театрознавства, в якому багато прогалин з історії розвитку українських театрів на сході країни. Культурно-історична еволюція українського театрального руху багатьох регіонів України, зокрема і Сєвєродонецька, на сьогодні $€$ недостатньо дослідженою. Відсутність опублікованих архівних матеріалів і фактів, які дають змогу скласти уявлення про етапи та форми становлення театрального мистецтва в цьому регіоні, ускладнює процеси наукових досліджень. Саме ці обставини і обумовили мету дослідження - схарактеризувати творчо-організаційну діяльність провідних режисерів Сєвєродонецька у XX столітті (О. Бірюстюкова, О. Шмаля та О. Олександрова) як складову еволюції театрального мистецтва на Луганщині.

\section{Виклад основного матеріалу}

Важливою ознакою театрального мистецтва в Сєвєродонецьку XX ст. є поліваріантність. Наявність у місті кількох театральних осередків відповідно і різних режисерів з їхніми відмінними мистецькими підходами дала змогу творчим містянам бачити абсолютно різний театр. Це у свою чергу виховувало публіку, розви- 
ваючи художній смак, і мало значний вплив на самих митців. Їхня діяльність, що характеризувалася певною конкуренцією за глядацький попит, стала основним двигуном розвитку театрального мистецтва міста.

Передвоєнні роки ввійшли в історію міста як роки інтенсивного промислового, громадського та культурного розвитку. У післявоєнний період театральне мистецтво Сєвєродонецька розпочинає історію з театрального колективу Палацу культури хіміків, який очолив у 1965 році В. Ажиппо, випускник театрального училища ім. Щукіна.

у 70-ті роки з'являється ще один колектив - театр юного глядача, який у 90-ті трансформується в Народний молодіжний театр під керівництвом О. Бірюстюкова.

О. Бірюстюков першим у місті створив театральний у загальноприйнятому значенні цього слова колектив. Йому вдалося не тільки об'єднати творчих людей в один гурток, а й пояснити їм специфіку театрального дійства. Актори його студії проводили тренінги, різноманітні вправи на розвиток елементів сценічної дії: м'язової свободи, уваги, уяви, темпоритму тощо. Згодом регулярні зустрічі творчих особистостей трансформувалися в перший у Сєвєродонецьку народний театр.

Аматорський театр в Україні виник у першій половині XVII ст. З'явився він приблизно водночас із фольклорним театром і навіть певною мірою замінив його. Проте між фольклорним та народним театром існували значні відмінності. Найвагомішою з них було те, що репертуар аматорського колективу базувався на драматургії професійних авторів, п'єсах «шкільного» театру та сатиричних комедіях, тимчасом як фольклорний театр ґрунтувався виключно на народній творчості. Значною перевагою аматорського театру була його доступність, своєрідна демократичність. Якщо двері кріпацького та аристократичного театру були відкриті виключно для придворної знаті, то народний колектив виступав абсолютно для всіх верств населення.

Народний театр Сєвєродонецька, окрім свого головного завдання - випуску вистав, значною мірою впливав на особистісний і культурний розвиток самих учасників колективу. Варто зазначити, що театральне мистецтво як таке відбивається на творчому потенціалі молоді, є своєрідним підготовчим етапом на шляху обирання та опанування професією, а якості, що розвиваються під час спільної роботи над сценічним видовищем, стають незамінними в процесі формування професійних амбіцій (Васильев, 1999).

Аматорський театр у свою чергу виконував роль своєрідного провідника між мистецтвом і нагальними проблемами тогочасного суспільного середовища. Діяльність колективу О. Бірюстюкова мала декілька принципово важливих для розвитку особистості функцій:

1. Креативна. Розвиває творче мислення людини та інтегрує зусилля на виконання подальших завдань.

2. Гуманістична. Впливає на особисту систему цінностей. Розвиває духовне сприйняття навколишнього світу та спонукає людину до самопізнання, самооцінки, самоідентифікації. Формує такі якості характеру, як гуманізм, справедливість, емпатія, толерантність. 
Вісник Київського національного університету культури і мистецтв.

Серія: Сценічне мистецтво

3. Інформаційно-професійна. Сприяє опановувати елементи акторської майстерності та поглиблює знання учасників аматорського колективу у сфері театрального мистецтва.

Діяльність любительського театру О. Бірюстюкова базувалася на спілкуванні. Саме воно було головним аспектом, що приваблював сєвєродонецьку молодь залучатися до спільної діяльності. У процесі спілкування учасники колективу набували комунікаційних навичок, училися пізнавати себе та співбесідника, збагачували власний життєвий і культурний досвід. Важливо, що якості, здобуті під час занять у театральній студії, мали довготривалий ефект.

Як і в 30-ті роки XVII ст. аматорський театр XX ст. у Сєвєродонецьку став своєрідною віддушиною для місцевого глядача. Окрім того, створення народного колективу, засновником якого був О. Бірюстюков, дало змогу розкрити свій потенціал багатьом «театралам» міста. Перевагою аматорського мистецтва того часу було безліч можливостей для творчих експериментів. Учасники гурту виявляли неабиякий інтерес і ентузіазм до постановок. Для деяких з них колектив був справжньою школою сценічного мистецтва. Досвід, здобутий там, став потужним підґрунтям для вступу до закладів вищої освіти культурно-мистецького спрямування.

Проте були й недоліки, які значною мірою ускладнювали роботу колективу. Насамперед заважала так звана «плинність кадрів». Річ у тім, що в молодіжному театрі грали непрофесійні актори, отож, згодом вони йшли, звільняючи місце для нових любителів театрального мистецтва. А враховуючи те, що театр для мешканців тогочасного міста був новим і майже незнайомим видом мистецтва, охочих долучитися до творчості було небагато. Через це репертуар студії не був стабільним, а вистави грали несистематично. Усе ж складнощі не були перепоною для режисера шукати нові трактування та цікаві образи.

Підтвердженням цього став мюзикл «Летючий голландець», який був абсолютно новою формою для тогочасного Сєвєродонецька. Згідно зі своїми жанровими ознаками мюзикл у постановці сєвєродонецького режисера О. Бірюстюкова поєднував у собі драматичне, музичне та хореографічне мистецтво. Рішення втілити за допомогою аматорського колективу цей досить складний в усіх сенсах сценічний матеріал актори студії сприйняли з деяким острахом. Аматорський театр О. Бірюстюкова не мав фінансової підтримки міської адміністрації, існував виключно на волонтерських засадах. Отож, матеріальної можливості виготовляти декорації, реквізит, костюми просто не було (Васильев, 1999).

Єдиними меценатами народного театру були його учасники - саме їхнім коштом купували необхідні матеріали. Щодо професійної підготовки також виникали певні складнощі. Враховуючи, що фахової освіти ні в кого з учасників колективу не було, процес випуску вистави займав не один місяць. Однак те, що в колективі були співаки, музиканти й танцівники, значно полегшувало роботу. Містяни сприйняли виставу із захватом і вдячністю. Саме така реакція надихнула учасників колективу та дала зрозуміти режисерові, що для студійців можна сміливо шукати нову драматургію для постановок, і що місцевий глядач потребує таких вистав. Одним з найбільш значущих досягнень Народного театру другої половини XX ст. стало визнання його найкращим з 53 аматорських театральних колективів України 1998 року (Васильев, 1999). 
Народний театр О. Бірюстюкова задовольняв духовні потреби сєвєродончан, збагачував їхній моральний досвід, розкривав творчі можливості учасників гуртка. Часто саме вони ставали «двигуном прогресу» і давали новий стимул для розвитку культури міста.

Отож, аналізуючи тенденції розвитку аматорського мистецтва Сєвєродонецька, можна зробити висновок, що театр О. Бірюстюкова відіграв украй важливу роль у культурному житті суспільства тих часів. Це збереження морально-естетичних засад, традицій, притаманних культурі міста й України в цілому, виховання безкорисливого служіння улюбленій справі, відчуття колективізму. Варто зазначити, що саме ці аспекти соціокультурного життя Сєвєродонецька XX ст. потребували особливої уваги з боку кожного, хто був небайдужим до стану духовного життя суспільства.

Подібно до того, як 1926 року Бертольд Брехт (1965, с.14) у статті «Про "народний театр"» у «еорії епічного театру» заперечував приналежність народного театру до театрального мистецтва, засуджуючи його діяльність як «продовжувача старого, відсталого театру», як "даремного розподільника театральних білетів між своїми членами», Олександр Шмаль заперечував репертуарний театр. Харківський режисер став засновником першого професійного театру міста Сєвєродонецька. Саме тоді, це був 1992 рік, О. Шмаль закінчив Харківський інститут мистецтв за спеціальністю режисура і вже зробив декілька власних постановок у Росії. Ідея створення першого професійного театру в Сєвєродонецьку стала не просто викликом для режисера, а його амбітною ідеєю. Він став наполегливо закликати до втілення своєї мети держструктури, шукати однодумців, і це виявилося результативним. Офіційною датою заснування Сєвєродонецького театру драми вважаємо 1993 рік.

Навколо молодого колективу згуртувалися також однокурсники режисера, яких зацікавив такий творчий задум О. Шмаля. Театр розпочав свою діяльність, спрямовуючи її насамперед на випуск нових постановок. Першочергове значення для акторів мали тренінги, які регулярно проводили у творчому колективі. Саме під час тренажів виконавці формували навички, які стали підґрунтям для створення авторської експериментальної програми акторської майстерності.

Погляди О. Шмаля певною мірою збігалися з акторською методикою Бертольда Брехта (1965). Згідно з традиційною тезою актор має бути цілковито відвертим з глядачем. Б. Брехт вважав навпаки: ступінь «нещирості» актора визначає його професійність. Якщо тлумачити наведену теорію більш детально, то можна сформулювати формулу: відвертість + відстороненість = професійність. Інакше кажучи, виконавець має поєднувати в собі дві іпостасі - персонажа та спостерігача. Саме через призму своєї «нещирості» актор має змогу помічати штампи, формальні емоції та позбуватися їх. Вагоме місце в авторській методиці режисера займало поняття «катарсису».

Термін винайшов філософ Аристотель, який детермінував його як очищення, примирення, що досягається за допомогою страждання та страху. У праці «Поетика» науковець уперше систематизував античні уявлення про естетичні категорії духовності. Аристотель (2007) схарактеризував поняття катарсису як утілення віри художника у вічне збереження і невмирущість цінностей, насамперед моральних. 
Вісник Київського національного університету культури і мистецтв.

Серія: Сценічне мистецтво

Проте варто зауважити, що уявлення про катарсис, подане у «Поетиці», досить узагальнене. Абстрактність судження, відсутність конкретики в детермінації поняття стали головним чинником появи численних інтерпретацій явища катарсису. 3 XIX cт. термін використовували для визначення впливу мистецтва на емоційний стан людини і застосовували здебільшого в естетиці. Згодом термін упроваджено у сферу психоаналітики та психотерапії, де словом «катарсис» позначали відчуття в пацієнта сильних переживань у стані гіпнозу.

Сьогодні ж це явище ідентифікують як «інсайт». Досліджуючи його терапевтичне значення, формулюють тезу щодо схожості поняття катарсису в контексті психотерапії та мистецтва, зокрема театрального. Максимально вдало, на нашу думку, характеристику терміна визначив психолог Л. Виготський (1982). Він стверджував, що прийом катарсису передбачає відтворення людиною у безпечних умовах тих емоцій та відчуттів, що в минулому були пригнічені. Тобто виникнення в людині за певних умов двоспрямованих емоцій і обумовлює явище катарсису. Інакше кажучи, суперечлива в якомусь сенсі форма та зміст об'єкта мистецтва викликають у глядача різнойменні почуття, що, стикаючись в завершальній точці, знищують одне одного (Выготский, 1987).

Для того, аби визначити, який ефект призводить одночасне переживання протилежних емоцій, звернемося до психології. Згідно з концепціями вченого І. Павлова (2016), який досліджував фізіологічний механізм виникнення психічного неврозу, виявляється, що внаслідок «зіткнення» різних емоцій у нервовій системі відбувається збудження та гальмування нервових імпульсів. Це у свою чергу призводить до так званого «нервового зриву». Резюмуючи отримані дані, можна зробити висновок щодо синтезування в авторській методиці О. Шмаля двох рівнозначних аспектів - мистецького та психологічного. Цей емоційний стан, у якому перебувають актори під час вистави, певно, був відчутний і глядачам. Проте не всі були готовими настільки сильно заглиблюватися в драматургічний матеріал і сприймати абсолютно нове трактування авангардного режисера.

Отже, репетиції проводили в актовій залі школи № 3, і вже через рік у Сєвєродонецькому театрі відбулася прем'єра вистави «Бродяги Далласа» за Майклом Фрейном. Варто зазначити, що цей драматургічний матеріал став доволі сміливим першим кроком, враховуючи консервативну публіку міста. Вибір на користь п'єси цього автора О. Шмаль зробив невипадково. Майкл Фрейн - англійський драматург, який починав письменницьку діяльність у ролі журналіста. На початку кар'єри, як зізнається сам автор, він ненавидів театр. Схильність до написання невеликих за обсягом публіцистичних статей з'явилася в М. Фрейна у віці дванадцяти років. Декілька років на початку свого професійного життя, у період студентства, М. Фрейн (2016) приділив спробам написання п'єс. Проте цей досвід не мав успіху. Потім альтернативним варіантом була ідея писати романи. А у віці сорока років драматург знову надихнувся створенням п'єс. Аналізуючи професійну біографію М. Фрейна, можна помітити певну схожість з творчими уподобаннями О. Шмаля. Притаманні харківському режисеру відчуження, новаторські підходи до оформлення вистави гармонійно перетиналися з неординарними поглядами на драматургію М. Фрейна. Форма вистави була повністю позбавлена побутовості. 
Мінімалізм, домішки авангардизму та використання символічних образів стали головною характеристикою вистави «Бродяги Далласа».

Наступними режисерськими роботами О. Шмаля стали вистави «I на Нірвану капає свіча...» та «Гамлет $є$ Гамлет, $є$ Гамлет, $є$ Гамлет...». Варто відзначити, що драматургічний матеріал режисер не використовував як основу, на якій базується вистава. Текст п'єс піддавали ґрунтовному редагуванню, компонували з текстами інших матеріалів, перефразовували. Форми тогочасних вистав О. Шмаля були близькими до сучасного перформансу, адже поєднували в собі епатажність, імпровізаційні моменти, дії, що балансують між сакральним та буденним, реальним та ірреальним.

Творча позиція О. Шмаля базувалася на тезисі, що режисерський стиль як такий - досить мінливе явище. Головний орієнтир - напрям театральної діяльності. Свій особистий напрям О. Шмаль називає «об'єктивним мистецтвом». Автором дефініції «об'єктивне мистецтво» вважаємо письменника, містика та композитора Г. Гурджиєва. Він пов'язував поняття об'єктивного мистецтва з рівнями розвитку людини. За його теорією цих категорій налічується сім. Люди, яких зараховуємо до 1-3 категорії розвитку, керуються внутрішніми імпульсами. Їх Г. Гурджиєв називає стандартними особистостями. Залежно від рівня (з 4 до 7 категорії) людина стає більш свідомою, здатною до кардинальних внутрішніх трансформацій. Справжнє мистецтво Г. Гурджиєв (1996) трактує як об'єктивне явище, що тяжіє до точних наук. У ньому відсутня імпульсивність, усе гранично точно та майже піддається математичному обчисленню. На людей з однаково високим рівнем розвитку об'єктивне мистецтво справить однакове враження. Ті, чия категорія розвитку нижча 4, не здатні сприйняти об'єктивне мистецтво апріорі.

Згідно з принципами об'єктивного мистецтва роль режисера визначається як генератор видовища, доступного активній уяві та недоступного пасивній. Щоб утілити це видовище, режисеру потрібен актор з унікальною творчою природою. Найвдалішими прикладами феноменального актора або режисера О. Шмаль називає Леся Курбаса, К. Станіславського, М. Чехова, П. Брука, Є. Гротовського.

Режисерська методика О. Шмаля близька до визначень Карла Юнга (1995). Сформована на основі емпіричних досліджень концепція колективного несвідомого полягає у філогенезі психіки людства та має в основі теорію архетипів. Згідно з нею в підсвідомості людей приховані психічні першообрази, від яких залежить характер, поведінка та здатність до інстинктивного пристосування в соціальному середовищі (Юнг, 1995). Працюючи з акторами, О. Шмаль керувався подібними тезами щодо закладеного в підсвідомості. До речі, як указував у своїй книзі «Психологічні типи» сам психіатр, досліджувати концепцію колективного несвідомого можна двома шляхами: через безпосереднє вивчення психіки людини або через вивчення давньогрецької міфології. Міфи є найбільш конкретною проєкцією внутрішніх психічних проявів суспільства. Аналізуючи акторську методику членів майстерні, варто відзначити, що вона також дещо відрізнялася від загальноприйнятої. Їй були притаманні риси брехтівського театру з властивою йому відстороненістю, повним заглибленням у запропоновані обставини зі збереженням водночас зовнішньої беземоційності. 
Досліджуючи питання несприйняття публікою вистав О. Шмаля, можна зробити висновок щодо відмінності об'єктивного мистецтва від принципів класичного театру. Між репертуарним театром і театром О. Шмаля, зі слів самого режисера, немає нічого спільного. Головною відмінністю О. Шмаль вважає різність надзавдання театральних колективів. Для традиційного в загальноприйнятому уявленні театру пріоритетом є робота виключно на публіку, на власну касу. Звідси витікає необхідність орієнтуватися на шкільну програму, аби певною мірою задовольнити освітні потреби середніх навчальних закладів. Згідно з позицією О. Шмаля його театр керувався більш глибокими принципами.

Обираючи драматургічний матеріал, режисер віддавав перевагу п'єсам американських та англійських авторів, зокрема Нілу Саймону, Майклу Фрейну. Проте, як було зазначено вище, О. Шмаль досить часто здійснював суттєві редагування обраних матеріалів, а деякі взагалі створював самостійно. Як приклад можемо навести виставу «I на Нірвану капає свіча...», яку повністю створив О. Шмаль: він $\epsilon$ автором і режисером.

У 1995 році О. Шмаль випускає другу частину - своєрідне продовження вистави «l на Нірвану капає свіча. Частина друга: Нарцис». За жанровими ознаками вистава належить до рок-опери. ІІй притаманна наявність арій, монологів, розмовних діалогів. Невід'ємними складовими є хор, різноманітні звукові та світлові ефекти, а також специфічна пластика виконавців. Характерною ознакою рок-опери є перевага колективу над особистістю. Інакше кажучи, окрему людину показано невідривною від маси, індивідуальні проблеми та переживання героя сприймаються виключно на фоні суспільства. Рок-опера стала абсолютно новою театральною формою для Сєвєродонецька. Отож, очевидно, що для більшості жителів міста новаторський стиль О. Шмаля був незрозумілим.

У 1998 році Сєвєродонецький міський театр драми очолив Олег Олександров. Першою виставою стала «Кротка» за п'єсою Ф. Достоєвського. Класичний матеріал привернув увагу місцевого глядача. Далі випустили вистави «Урок», «МАМАКЛАBA». Епатажність та авангардність режисерських методів прослідковуємо навіть через призму обирання п'єс.

Ежен Йонеско - один із засновників естетичного абсурдизму. Драматург прагнув створити мистецтво, вільне від політичної ідеології. Під час створення п'єс, він був натхненний примарними образами, власними сновидіннями, а не чітко встановленою ідеєю. Цікаво, що з раннього дитинства автор не любив драматичний театр, віддаючи перевагу ляльковому. Це знайшло відображення в його літературних героях. Вони дійсно мають чимало спільного з маріонетками: схожі на роботів, що не можуть висловити своїх думок, не впливають на власне життя, а піддаються течії, яка приводить до якогось пародійного результату. Атмосфера його творів - гротескна, проте, вдивляючись у сутність, можна побачити невимовно глибокий трагізм.

Творчість Е. Йонеско стала новим етапом у розвитку драматургії, а у 1998 році вплинула й на Сєвєродонецький театр. Адже місцева публіка, яка тільки-но познайомилася з постановками О. Шмаля, не менш приголомшливими та провокаційними, побачила абсолютно новий світ авангарду. Максимальну кількість інновацій вико- 
ристано у виставі «Подорож у відкритому серці», в якій О. Олександров застосував величезну кількість технічних можливостей сцени: різноманітні світлові ефекти, вітер, дощ. Музичне оформлення виявилося не менш новаторським - робота була насичена творами Арво Пярта. Особливість полягала в техніці створення: за основу композитор брав релігійні тексти і кодував їх у вигляді числа, що фіксувало кількість складів у слові, після чого перетворювалося на музичний мотив. Свій стиль А. Пярт назвав тінтінабулі, що в перекладі з латинської означає «дзвіночки» (Нестьева, 1990, с.121).

Дійсно, унаслідок математичних розрахунків і маніпуляцій виходила досить повільна медитативна мелодія. За формою вистави були наближені до сучасного перформансу. Сценографія робіт О. Олександрова мала певні особливості та відмінності від постановок інших режисерів міста. Головним чином, ця різність полягала у яскравості, гротескності, «кричущих» кольорах сценічного оформлення. Розраховували саме на епатування глядача відвертими діалогами дійових осіб, зовнішнім виглядом персонажів і пластичним оформленням. У цілому характерною рисою вистави була насиченість прямолінійним еротизмом. Як стверджував сам режисер, цю форму використано свідомо, аби привернути увагу глядача, зацікавити його. Основою вистави були глибокі переживання персонажів, порушення головних питань про дружбу, любов, милосердя та справедливість. І це спрацювало: глядачі, які на початку вистави були збентежені екстремальною відвертістю режисера, наприкінці аплодували стоячи зі сльозами на очах.

У виставі «Осінні квіти» О. Олександров також вирішив використати інноваційний на той час прийом - покласти в основу вистави вірші місцевої поетеси. Проте нова форма справила неоднозначне враження на сєвєродонецьких глядачів.

Наукова новизна. Уперше систематизовано та аналітично осмислено творчоорганізаційну діяльність О. Бірюстюкова, О. Шмаля та О. Олександрова в контексті еволюції театрального мистецтва Сєвєродонецька у XX ст.

\section{Висновки}

Підсумовуючи вищезазначене, можна стверджувати, що сєвєродонецький аматорський театральний колектив під орудою О. Бірюстюкова завдяки своїй організаційно-творчій діяльності виконував не тільки культурні, а й освітньо-виховні функції. Творчо-організаційна діяльність О. Шмаля стала сучасною імплементацією принципу «об'єктивного мистецтва» Г. Гурджиєва, зокрема через упровадження авторської методики роботи з акторами. Режисура О. Олександрова збагатила палітру театрального життя Сєвєродонецька своєю епатажністю та авангардизмом.

Загалом порівняльна коротка історія розвитку театрального мистецтва Сєвєродонецька свідчить про те, що динаміку цього процесу визначила тенденція, яка характерна і для загальнонаціональних процесів становлення українського театрального життя: від самодіяльних його форм до професійних. Аналіз останніх свідчить про їхній активний розвиток завдяки використанню нових режисерських підходів, які сприяли зростанню акторської майстерності колективів і збагаченню репертуарної палітри щодо відродження національних культурних традицій. 
Режисерські пошуки та організаційно-творча діяльність О. Бірюстюкова, О. Шмаля та О. Олександрова стали вагомим внеском у розвиток театрального мистецтва Сєвєродонецька у XX ст. - воно стрімко та різновекторно розвивалося від локального аматорського театрального колективу однодумців до провідного регіонального професійного театрально-видовищного закладу культури.

\section{СПИСОК ПОСИЛАНЬ}

Аристотель, 2007. Поетика. В: М. Борецький та В. Зварич, упоряд., Античні поетики. Київ: Грамота.

Брехт, Б., 1965. О «народном театре». В: Театр: Пьесы. Статьи. Высказывания. Перевод: В. Клюева. Москва: Искусство. Т.5, Ч.2.

Васильев, А., 1999. Северодонецкий театр «Драмы и абсурда». Опыт субъективной хроники семилетнего цикла. Северодонецк-online, [online] Доступно: <http://www.sed.lg.ua/ culture/teatr/teatrdramy.html> [Дата обращения 2 февраля 2020]

Выготский, Л.С., 1982. История развития высших психических функций. В: Собрание сочинений. Москва: Педагогика. Т. 3.

Выготский, Л.С., 1987. Психология искусства. Москва: Педагогика.

Гурджиев, Г.И., 1996. Жизнь реальна только тогда, когда есть я. Перевод с английского языка А. Гаспаряна. Санкт-Петербург: Невский курьер.

Дорогих, Л., 1998. Аматорське мистецтво як історико-культурне явище (на матеріалах України другої половини XIX cт.). Автореферат кандидата наук. Київський державний університет культури і мистецтв.

Нестьева, М., 1990. Берлинские каникулы. Советская музыка, 12, с.121.

Павлов, И.П., 2016. Лекции о работе больших полушарий головного мозга. Москва: Эксмо. Токарева, М., 2016. Майкл Фрейн: «Какважно выйти из собственных ботинок». Новая газета, [online] 19 октября. Доступно: <https://www.novayagazeta.ru/articles/2016/10/19/70231maykl-freyn-kak-vazhno-vyyti-iz-sobstvennyh-botinok> [Дата обращения 2 февраля 2020]. Юнг, К.Г., 1995. Психологические типы. Москва: Прогресс-Универс.

\section{REFERENCES}

Arystotel, 2007. Poetyka [Poetics]. In: M. Boretskyi and V. Zvarych, ed., Antychni poetyky [Ancient Poetics]. Kyiv: Hramota.

Brekht, B., 1965. O "narodnom teatre" [About the "folk theater"]. In: Teatr: Pesy. Stati. Vyskazyvaniia [Theater: Plays. Articles. Sayings]. Translation by V. Klyuyev. Moscow: Iskusstvo. Vol.5, Ch.2.

Dorohykh, L., 1998. Amatorske mystetstvo yak istoryko-kulturne yavyshche (na materialakh Ukrainy druhoi polovyny XIX st.) [Amateur art as a historical and cultural phenomenon (on the materials of Ukraine of the second half of the nineteenth century)]. Abstract of the candidate of sciences. Kyivskyi derzhavnyi universytet kultury i mystetstv.

Gurdzhiev, G.I., 1996. Zhizn realna tolko togda, kogda est ia [Life is real only when I am]. Translation from English by A. Gasparyan. St. Petersburg: Nevskii kurer.

lung, K.G., 1995. Psikhologicheskie tipy [Psychological types]. Moscow: Progress-Univers. Nesteva, M., 1990. Berlinskie kanikuly [Berlin Vacations]. Sovetskaia muzyka, 12, p.121. 
Pavlov, I.P., 2016. Lektcii o rabote bolshikh polusharii golovnogo mozga [Lectures on the work of the large cerebral hemispheres]. Moscow: Eksmo.

Tokareva, M., 2016. Maikl Frein: "Kak vazhno vyiti iz sobstvennykh botinok" [Michael Frein: "How important it is to get out of your own shoes"]. Novaia gazeta, [online] 19 October. Available at: <https://www.novayagazeta.ru/articles/2016/10/19/70231-maykl-freyn-kak-vazhno-vyyti-izsobstvennyh-botinok> [Accessed 2 February 2020].

Vasilev, A., 1999. Severodonetckii teatr "Dramy i absurd". Opyt subektivnoi khroniki semiletnego tcikla [Severodonetsk theater "Drama and absurdity." The experience of subjective chronicles of the seven-year cycle]. Severodonetsk-online, [online] Available at: <http://www.sed.Ig.ua/culture/ teatr/teatrdramy.html> [Accessed 2 February 2020].

Vygotskii, L.S., 1982. Istoriia razvitiia vysshikh psikhicheskikh funktcii [The history of the higher mental functions development]. In: Sobranie sochinenii [Collected Works]. Moscow: Pedagogika. Vol. 3.

Vygotskii, L.S., 1987. Psikhologiia iskusstva [Psychology of art]. Moscow: Pedagogika.

\title{
ХУДОЖЕСТВЕННЫЕ ПОИСКИ РЕЖИССЕРОВ СЕВЕРОДОНЕЦКА ХХ ВЕКА
}

\author{
Светлана Уланова ${ }^{1 a}$, Кирил Майкут ${ }^{2 a}$, Анастасия Адначева-Пономаренко \\ ${ }^{1}$ доктор философских наук, профессор; e-mail: golubtsova@i.ua; ORCID: 0000-0001-5463-5659 \\ ${ }^{2}$ магистр; e-mail: kirillmaik@ukr.net; ORCID: 0000-0003-1012-697X \\ ${ }^{3}$ магистр; e-mail: nastaponomarenko366@gmail.com; ORCID: 0000-0003-0693-0973 \\ а Луганская государственная академия культуры и искусств, Киев, Украина \\ ' Луганский областной академический украинский музыкально-драматический театр, \\ Северодонецк, Украина
}

\begin{abstract}
Аннотация
Цель исследования - охарактеризовать творческо-организационную деятельность ведущих режиссеров Северодонецка в XX в. Методология исследования. В процессе исследования использованы следующие методы: исторический - для осмысления фигур А. Бирюстюкова, А. Шмаля и О. Александрова в театральном искусстве Северодонецка; историко-биографический - для анализа контекста эпохи и эстетико-художественных векторов времени, влияющих на формирование художественных подходов указанных художников; компаративно-типологический - для дифференцированного сравнения творчества режиссеров. Научная новизна. Впервые систематизирована и аналитически осмыслена творческо-организационная деятельность А. Бирюстюкова, А. Шмаля и О. Александрова в контексте эволюции театрального искусства Северодонецка в XX в. Выводы. Северодонецкий народный театр под руководством А. Бирюстюкова выполнял не только социокультурные, но и образовательно-воспитательные функции. Творческоорганизационная деятельность А. Шмаля стала современной имплементацией принципа «объективного искусства» Г. Гурджиева, в частности с помощью внедрения авторской
\end{abstract}


методики работы с актерами. Режиссура О. Александрова обогатила палитру театральной жизни Северодонецка своей эпатажностью и авангардизмом. В общем относительно короткая история развития театрального искусства Северодонецка свидетельствует о том, что динамику данного процесса определила тенденция, присущая и общенациональным процессам становления украинской театральной жизни: от самодеятельных его форм до профессиональных. Анализ последних свидетельствует об их активном развитии благодаря использованию новых режиссерских подходов, способствующих росту актерского мастерства коллективов и обогащению репертуарной палитры в направлении возрождения национальных культурных традиций. Режиссерские поиски и организационнотворческая деятельность А. Бирюстюкова, А. Шмаля и О. Александрова стали весомым вкладом в развитие театрального искусства Северодонецка в XX в. - оно стремительно и разновекторно развивалось от локального любительского театрального коллектива единомышленников к ведущему региональному профессиональному театрально-зрелищному учреждению культуры.

Ключевые слова: театральное искусство; XX век; Северодонецк; режиссер А. Бирюстюков; А. Шмаль; О. Александров

\title{
ART SEARCH FOR DIRECTORS OF THE SEVERODONETSK IN XX CENTURY
}

\section{Svitlana Ulanova ${ }^{1 a}$, Cyril Maykut ${ }^{2 a}$, Anastasya Adnacheva-Ponomarenko ${ }^{3 b}$}

${ }^{1}$ Doctor of Philosophy, Professor; e-mail: golubtsova@i.ua; ORCID: 0000-0001-5463-5659

${ }^{2}$ Master; e-mail: kirillmaik@ukr.net; ORCID: 0000-0003-1012-697X

${ }^{3}$ Master; e-mail: nastaponomarenko366@gmail.com; ORCID: 0000-0003-0693-0973

${ }^{a}$ Lugansk State Academy of Culture and Arts, Kyiv, Ukraine

${ }^{b}$ Regional Academic Ukrainian Music-Dramatic Theater, Severodonetsk, Ukraine

\begin{abstract}
The purpose of the research is to characterize the creative and organizational activities of the leading directors of Severodonetsk in the twentieth century. Research methodology. In the research process, the following methods have been used: historical is to comprehend the figures of O. Biryustyuk, O. Shmal, and O. Oleksandrov in the theater art of Severodonetsk; historical and biographical are to analyze the context of the epoch and aesthetic and artistic vectors of time, which influenced the formation of artistic approaches of these artists; comparative-typological is for differentiated comparison of creative work of directors. Scientific novelty. For the first time the creative and organizational activities of 0 . Biryustyuk, 0 . Shmaly and O. Oleksandrov have been systematized and analytically analyzed in the context of the evolution of Severodonetsk theater art in the XX century. Conclusions. The Severodonetsk People's Theater under the direction of O. Biryustyuk performed not only socio-cultural but also educational and educational functions for the locals. O. Shmal's creative and organizational activity became a modern implementation of G. Gurdjiev's principle of "objective art", in particular through the introduction of the author's method of working with actors. Director 0 . Alexandrov enriched the palette of the theatrical life of
\end{abstract}


Severodonetsk with his epithet and avant-gardism. On the whole, the relatively short history of the development of the Severodonetsk theater art shows that the dynamics of this process have been determined by a tendency that is characteristic of national processes of the Ukrainian theatrical life formation: from amateur forms to professional ones. The analysis of the latter testifies to their active development through the use of new directorial approaches that contributed to the growth of the acting skills of the collectives and the enrichment of the repertoire palette for the revival of national cultural traditions. Directed searches and organizational and creative activity of O. Biryustyukova, O. Shmal and O. Oleksandrov made a significant contribution to the theater art development of Severodonetsk in the XX century and it has evolved rapidly and multifaceted from a local amateur theater group of like-minded people to a leading regional professional theater and entertainment institution of culture.

Keywords: theater art; the twentieth century; Severodonetsk; director O. Biryustyuk; O. Schmal;

O. Alexandrov 